\title{
The damage caused by Fake News in the human psyche
}

\section{Thamiris Gabriele Paula Silva de Souza ${ }^{1 *}$, Danilo Barros da Silva ${ }^{1}$; Eduardo Felipe Souza Silva ${ }^{1}$; Lívia Caroline da Conceição Pereira'; Thaliane Rafaele Silva de Melo;}

1 Department of Psychology, Center for Humanities, University Center of Vitória de Santo Antão (UNIVISA), Vitória de Santo Antão, Brazil E-mail adresse: thamirisgabriele2001@hotmail.com (Thamiris Gabriele Paula Silva de Souza), thalianerafaele11@gmail.com (Thaliane Rafaele Silva de Melo), liviaccpereira84@gmail.com (Lívia Caroline da Conceição Pereira), 7duard9@gmail.com (Eduardo Felipe Souza Silva), danilobarros99@hotmail.com (Danilo Barros da Silva).

*Corresponding author

\section{To cite this article:}

Souza, T.G.P.S.; Silva, D.B.; Silva, E.F.S.; Pereira, L.C.C.; Melo, T.R.S. The damage caused by fake news in the human psyche. International Journal of Sciences. Vol. 1, No. 1, 2021, pp. 5-10.

Received: 01 28, 2021; Accepted: 01 31, 2021; Published: 02 02, 2021

\begin{abstract}
Fake News is conceptualized as the dissemination of false information, with the intention of causing disorder or hurting something or someone. It can be seen that the psyche of the victims of this type of propagation is little portrayed, leaving them in oblivion; this article aims to show that there is a danger to be attacked in the face of those harmed by this fallacy, bringing real data through a questionnaire applied to an eclectic group, generating results with the help of Statistical Package for Social Sciences (SPSS) software and thus being able to carefully analyze all the data obtained so that it could reach a conclusive result. The feelings caused in the victims after the act of Fake News, if not treated in the proper way with proper psychological followup, can be aggravated by bringing bigger problems in the future, taking into account that there are several paths that the mind can resort to when one is in a moment of panic; Due to the above considerations, it is feasible that the Ministry of Education and Culture (MEC) and the Unified Health System (SUS) step up the methods about all involved; going directly to the root of the problem and making people aware of the problems they can cause to others with small attitudes and offering psychological support to those who have been damaged, so that one can avoid worse problems.
\end{abstract}

Keywords: Fake News; Damage to Psyche; SPSS; MEC, SUS.

\section{Introduction}

According to Bittencourt and Santos (2019) and their interpretation according to the text, it is understood that fake news is the misinformation disclosed through communications vehicles with the intention of defaming or causing disorder about something or someone. It should also be recorded that the damage caused by this type of news in the human mind, is a fact to consider and requires special attention, where "in addition to spreading lies, this news can cause a feeling of invasion and impotence." (REVISTA MINHA VIDA, 2018), thus generating space for other feelings, that if there is no correct discernment to control them, it is possible that extreme situations will happen (BRANCO, 2017) the psyche of the person involved, as even in the worst case, the involvement of suicide. It is clear and sustained the idea that the spread of false information brings a real danger to life (BRAGA, 2018), when one observes real cases that have brought irreparable harm to the victims of this problem; as in a case cited by the Journal of the Federal University of Goiás in 2008, where General Marcos Antônio after receiving the false news that his wife had died, soon came to withdraw his own life. Nowadays, it is notorious the attention that the Brazilian Government is giving to this problem, it is being of great value; where through awareness campaigns, news and other media, the importance of not sharing fake news is being shown. However, what initiative will be taken to welcome people who have already been victims of this problem? It should be emphasized that some of those who have experienced this situation are already psychologically damaged.

\section{Methodology}


146 questionnaires were generated created through the Google platform, and forwarded to people online, among a diverse audience. After being answered, data collection served as input for statistical analysis using statistical package for social sciences (SPSS) software.

\section{Results and Discussion}

Among the most important results, we observed that all the victims of fake News harbored some kind of feeling by the news producer, even after going through the embarrassing situation. There was the observation of a mixture of feelings in the victims of the fake News, going from shame, humiliation, sadness, and indifference to veiled resentment. Since the grudge is, the feeling that most prevails among the others $(65 \%)$ that added to the other feelings brings an overload to the involved. The amount of feelings that follow in the minds of those affected is a problem that can lead to the numerous pathways of mental disorders, resulting in ailments so severe to the mind that, when not treated in time, it can progress to a significant and fatally irreversible worsening (Figure 1)

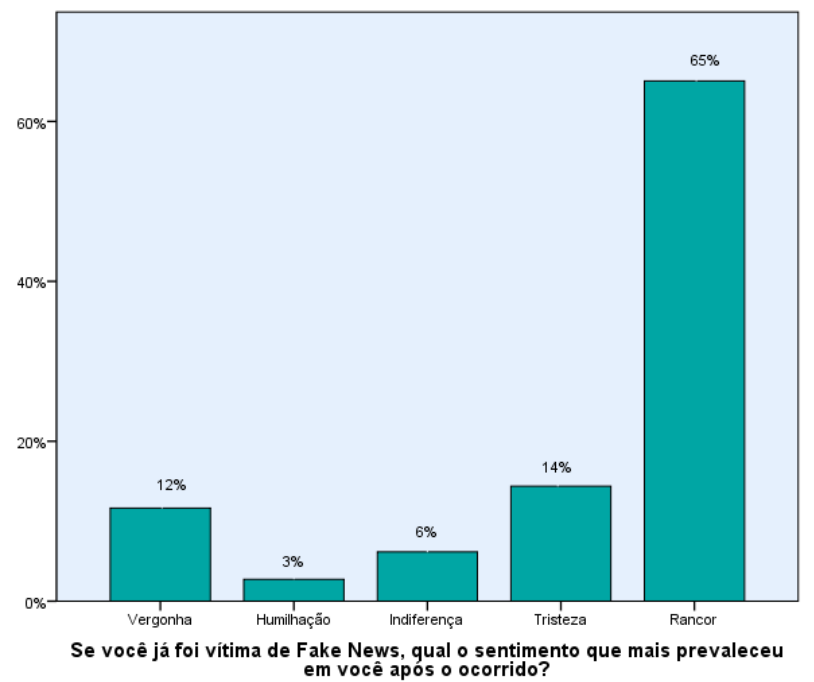

Figure 1. 2D bar chart indicating the feelings expressed by the victims of fake news. ${ }^{*}$ Graph generated by SPSS version 22.0 software.

\section{Conclusions}

By virtue of the facts, it is proven that fake news can cause evil to the human mind through feelings that if not treated in time can increase significantly and that, from this, triggered damage can arise. Psychological follow-up is essential for the victim, because what an individual hears can be reflected in his actions making him ignorant, frustrated, problematic and depending even on a specific mental trigger, suicidal. It is then evident that the intervention of the authorities in the punishment of the authors of network rumors is increasingly emergency, and that this topic should be widely discussed under the reins of the State, taking into account the risk to human rights: right to the life of the person involved and their health. It is also good to mention the participation of the Unified Health System (SUS) in the use of strategic methods so that it can offer psychological support to people involved in this type of situation. The MEC (Ministry of Education and Culture) is reserved the obligation to elaborate educational advertisements, which clarify the seriousness of the problem, since it can bring real problems not only to the psyche but also to the integrity of the entire population; definitely cutting this evil "by the root".

\section{Acknowledgements}

We thank Professor Pierre Teodosio for his help in all stages of this work..

\section{References}

[1] BRANCO, Sérgio. Fake news e os caminhos para fora da bolha. Revista Interesse Nacional. São Paulo/SP. 2017.

[2] BITTENCOURT, H.B.; SANTOS, G.L. Fakes news e sua categoria tipológica de violência na contemporaneidade. Revista da Sociedade de Psicologia do Rio Grande do Sul. Porto Alegre/RS. 2019.

[3] BRAGA, Renê Morais da Costa. A indústria das fake news e o discurso de ódio. In: PEREIRA, Rodolfo Viana (org.). Direitos políticos, liberdade de expressão e discurso de ódio: Volume I. Belo Horizonte/MG. Instituto para o Desenvolvimento Democrático, 2018.

[4] MEDEIROS, Magno. Fake news matam. Jornal da UFG. Goiânia/GO. 2018.

[5] REVISTA MINHA VIDA. Fake News pode trazer consequências para a saúde mental., 2018. Disponível em: $<$ https:/www.minhavida.com.br/bem-estar/materias/33946fake-news-podem-trazer-consequencias-para-a-saude-mentalentenda>. Acesso em: 25 de novembro de 2020. 